\title{
The Music Room: Betty Freeman's Musical Soirées
}

\author{
JAKE JOHNSON
}

\begin{abstract}
For over ten years, Los Angeles arts patron Betty Freeman (1921-2009) welcomed composers, performers, scholars, patrons, and invited guests into her home for a series of monthly musicales that were known as 'Salotto'. In this article, I analyse Freeman's musicales within a sociological framework of gender and what Randall Collins calls 'interaction rituals'. I contextualize these events, which took place in a space in her Beverly Hills home known as the Music Room, within a broader history of salon culture in Los Angeles in the twentieth century - a history that shaped the city's relationship with the artistic avant-garde and made Los Angeles an important amplifier for many of the most important voices in contemporary Western art music of the last sixty years.
\end{abstract}

Music critic W. J. Henderson begins his satirical novel of 1912, The Soul of a Tenor, with the following enigmatic scene:

Mrs. Harley Manners, just stepping from her car in front of the Waldorf-Astoria, was a vision of radiant expectancy. She was hastening to one of those perfectly delightful Monday morning musicales at which, for an inconsiderable price, you could sit and rub shoulders with people right in the heart of the smart set. Mrs. Harley Manners was not in that set. She knew many people in it, and purred audibly when they spoke to her. When they did not, which was the more usual occurrence, she retained her composure and waited. She knew that all of them would have to speak to her from time to time, for she was a cheerful and insistent laborer on all sorts of committees for charitable entertainments, benefits, and what not. She was always ready to do most of the work, all of the talking, and to sign a really handsome check. ${ }^{1}$

A few paragraphs later, Mrs Harley Manners arrives at the musicale and 'step [s] from her olive limousine just as if she were one of the elect'. Described as 'prattling vivaciously and saying all sorts of priceless nothings', her character is so obtusely constructed that her attendance at 'those perfectly delightful Monday morning musicales' obviously smacks of authorial derision. Mrs Harley Manners's social life at these musicales is frequently thwarted by the dashing music critic Philip Studley, whose exaggerated perspicuity and forthright presence set up the joke Henderson perpetuates throughout the story with a wink and a nod. Yet The Soul of a Tenor is more than just a tongue-in-cheek autobiographical jest. The character

Email: jvjohnson@okcu.edu .

Many thanks to my many interlocutors for this project, including Betty Freeman, Alan Rich, Steve LaCoste, and Danlee Mitchell. I also am indebted to Michael Lee, Jennifer Saltzstein, Mitchell Morris, and anonymous reviewers for their feedback and suggestions on earlier drafts.

1 W. J. Henderson, The Soul of a Tenor: A Romance (New York: Henry Holt and Company, 1912), 1-2. 
names themselves hint of an allegory. If Henderson could satirize the dynamics between high society women and the music critic, it only succeeds because his audience knew it was in on the joke.

The typical history of the musicale, the salon, the soiree is fraught with overwrought stereotypes and assumptions not unlike Henderson's. The playfulness can be appreciated, of course, as stereotypes are convincing only so far as they are rooted in experience. Yet it must be admitted there is more to the salon than its caricatured keepers such as Mrs Harley Manners or Proust's Madame Verdurin. The influence of the cultural salon, which has its beginnings in pre-Enlightenment France, has been contested for centuries. Unsurprisingly, much of the criticism surrounding the salon was then and continues to be focused on gender roles. Rousseau's misogynistic fervour is somewhat masked by his claim that, central to the organization of the salon, respecting the least deserving women showed a lack of respect for women in general:

The most esteemed woman is the one who has the greatest renown, about whom the most is said, who is the most often seen in society, at whose home one dines the most, who most imperiously sets the tone, who judges, resolves, decides, pronounces, signs talents, merit, and virtues their degrees and places, and whose favor is most ignominiously begged for by humble, learned men ... In society they do not know anything, although they judge everything. ${ }^{2}$

Rousseau's position is not that hard to knock off base. Dena Goodman argues that Rousseau was mostly bothered not by the presence of 'good women' but that 'men lowered themselves to earn the admiration of (bad) salon women'. ${ }^{3}$ While Rousseau's concern may in fact be grounded in the particular, his passioned dismissal of women in salon culture as 'arbiters of public opinion' positions his paranoia on a conspiratorial level. ${ }^{4}$ In truth, a conspiracy of a different kind was taking shape. Goodman and others have heartily evidenced the role of French salons in fostering a habitable environment for Enlightenment philosophies to take root. The popular conception of the salon as a 'frivolous place in which earnest philosophes were distracted from their work by foolish but seductive women' should not remain unchallenged. ${ }^{5}$ Women, as primary (though not sole) 'arbiters of public opinion' in salon culture, are deeply connected within the history of ideas and the structure of their exchange.

The salon-situated exchange of ideas was no less prevalent in the twentieth century than it was in Rousseau's time. Important private concerts and events such as Schoenberg's Society for Private Musical Performances in Vienna or the many private gatherings hosted

2 Jean-Jacques Rousseau, Politics and the Arts: Letter to M. d'Alembert on the Theatre, ed. and trans. Allan Bloom (Ithaca: Cornell University Press, 1968), 49.

3 Dena Goodman, The Republic of Letters: A Cultural History of the French Enlightenment (Ithaca: Cornell University Press, 1994), 54.

4 Quoted in Goodman, The Republic of Letters, 56 n. 5.

5 Goodman, The Republic of Letters, 84. 
by American patrons such as Elizabeth Sprague Coolidge and Mildred Bliss helped shape Western art music over the course of the century. ${ }^{6}$ Still, the salon as a mediated space for ideas to be vetted and networks established and reinforced has almost exclusively been explored as an eighteenth- and nineteenth-century phenomenon. In musicological circles the concept of the salon, when given serious attention at all, almost inevitably becomes reduced to Franz Schubert's house gatherings (the 'Schubertiade') and the burgeoning romantic sensibility of the early nineteenth century. As I explore here, however, the spirit of salon culture continued to move upon patrons, composers, scholars, and performers in places and times far removed from Schubert's 1820s Vienna, like west Los Angeles in the 1980s. In this article, I analyse the famous musicales of Los Angeles patron Betty Freeman within a sociological framework of gender and what Randall Collins, following Erving Goffman, calls 'interaction rituals' I contextualize Freeman's musicales, which took place in a space in her Beverly Hills home known as the Music Room, within a broader history of salon culture in Los Angeles in the twentieth century - a history that shaped the city's relationship with the artistic avant-garde and made Los Angeles an important amplifier for many of the most important voices in contemporary Western art music of the last sixty years.

\section{Salons and the public sphere}

Within intellectual debates salon culture has a distinct relationship with 'public opinion' and other matters of public import and dissemination. In The Structural Transformation of the Public Sphere, Jurgen Habermas constructs what has become the central theory on the concept of a 'public sphere'. Habermas argues that bourgeois identity in eighteenth-century Europe was born out of a conceptual space between private and authoritarian functions. This intermediate space, nurtured through interactions in salons or coffeehouses, enabled the exchange of anti-authoritarian ideas under the guise of a 'public sphere'.

The bourgeois public sphere may be conceived above all as the sphere of private people come together as a public; they soon claimed the public sphere regulated from above against the public authorities themselves, to engage them in a debate over the general rules governing relations in the basically privatized but publicly relevant sphere of commodity exchange and social labor. The medium of this political confrontation was peculiar and without historical precedent: people's public use of their reason. ${ }^{7}$

6 For a fuller account of the role women played in fostering American art music, see Ralph P. Locke and Cyrilla Barr, eds., Cultivating Music in America: Women Patrons and Activists since 1860 (Berkeley and Los Angeles: University of California Press, 1996) and Cyrilla Barr, Elizabeth Sprague Coolidge: American Patron of Music (New York: Schirmer Books, 1998).

7 Jurgen Habermas, The Structural Transformation of the Public Sphere: An Inquiry Into a Category of Bourgeois Society, translated by Thomas Burger (Cambridge, MA: MIT Press, 1989), 27. 
Contemporary interpretations of Habermas's thesis have expanded to embrace not just the primacy of oral transmission of ideas, as Habermas initially argued, but also that of print media. Michael Warner refocuses Habermas's claims to include texts, suggesting that 'the notion of a public enables a reflexivity in the circulation of texts among strangers who become, by virtue of their reflexively circulating discourse, a social entity'. ${ }^{8}$ In Publics and Counterpublics, Warner contends with contemporary crises within the public sphere by suggesting the term 'counterpublic' to describe smaller factions that, through conflict, form explicitly in opposition to wider publics. 'Counterpublics are, by definition, formed by their conflict with the norms and contexts of their cultural environment, and this context of domination inevitably entails distortion', Warner explains. 'Mass publics and counterpublics, in other words, are both damaged forms of publicness, just as gender and sexuality are, in this culture, damaged forms of privacy. ${ }^{\prime 9}$

Notions of private and public, of what impact and through what vehicles a social collective can manifest a particular ideology, are the central concern of this article. My reading of Habermas, through Warner, is that the concept of 'public' may be articulated less as an object of inspection than as a kind of work that people do. I take Habermas seriously when he writes,

The subject of this publicity is the public as carrier of public opinion; its function as a critical judge is precisely what makes the public character of proceedingsin court, for instance-meaningful ... The public sphere itself appears as a specific domain-the public domain versus the private. Sometimes the public appears simply as that sector of public opinion that happens to be opposed to the authorities. $^{10}$

Conceiving salon gatherings as a space where 'this publicity is the public as carrier of public opinion' repositions salon culture as not only a space where ideas are exchanged but also the means of exchange itself.

Randall Collins's recent sociology of intellectuals also contributes to Warner's concept of a counterpublic as a space where information exchange, framed around disruption, can take place. Adopting Erving Goffman's phrase 'interaction ritual' to refer to encounters that 'produce an ongoing flow of social motivations', Collins argues that intellectuals generate 'cultural capital' at these gatherings primarily because of the physical, face-toface environment and intense attention afforded to intellectual discourse. As Collins points out, ideas are created and disseminated, even in an age of sophisticated technology, primarily through gathering spaces:

Intellectuals set themselves apart from other networks of social life in the act of turning towards one another. The discussion, the lecture, the argument, sometimes the demonstration or the examination of evidence: these are the concrete

8 Michael Warner, Publics and Counterpublics (New York: Zone Books, 2002), 11-12.

9 Warner, Publics and Counterpublics, 63.

10 Habermas, The Structural Transformation of the Public Sphere, 1-2. 
activities from which the sacred object 'truth' arises ... It is exactly these faceto-face structures which are most constant across the entire history of intellectual life. ${ }^{11}$

From Collins's perspective, the essential nature of physical gathering creates the energy, or what Bourdieu calls cultural capital, needed for ideas to flourish. In Habermasian terms, these intellectuals not only gather in the public sphere but also create the public sphere itself. And from Warner's view, the intellectual organization around a central 'text' distinguishes the social entity.

Constructing the history of philosophy according to the broad theory that only a few can inhabit the upper echelons of the conceptual intellectual space, Collins suggests the terms 'major', 'secondary', and 'minor' to organize and measure the intellectual impact of individuals. This is important in terms of the amount of creative depth a group possesses: 'As we get farther from the major figures ... it becomes increasingly characteristic for philosophers to develop the ideas of a lineage chief, to add criticisms, explications, and commentaries. They are not creative precisely because they are followers. ${ }^{12}$ Collins's dichotomy of innovators and imitators is built around what he calls 'the opportunity structure'. Such a structure has place for only select people and ideas at any time:

Intellectual fields allow only certain possibilities to flourish at a given time. To know about these possibilities, to have a sense of what is opening up, it is crucial to be in the thick of things, and especially to be in contact with one's rivals. Thus, major intellectuals meeting one another do not necessarily communicate any intellectual capital; they may not learn anything at all substantive from one another. ${ }^{13}$

Those who gather at salons, then, do so to enact a similar interaction ritual. Composers, artists, writers, and intellectuals must necessarily meet often with one another in order for cultural stagnation to be thwarted. Creativity may happen in isolation but, as Collins argues, those ideas likely will not enter the marketplace of idea exchange and thus will not reach the potential for eminence. Isolated creativity also loses the distinction of a counterpublic. Gatherings such as salons or intellectual conferences remain so novel that their presence alone challenges the cultural space surrounding them.

The story of the Music Room, therefore, is not just a story of shared experiences positioned around exchanging ideas about contemporary music. The guests who gathered regularly, as well as the composers and performers, did so probably for a mixture of private and public reasons. Intentional or not, social systems and networks collided, old bonds were dissolved and new ones forged, and, like their French counterparts of the Enlightenment era, ideas were shared, accepted, modified, and dismissed under complex systems of coded behaviour

11 Randall Collins, The Sociology of Philosophies: A Global Theory of Intellectual Change (Cambridge, MA: Harvard University Press, 1998), 25.

12 Collins, The Sociology of Philosophies, 62.

13 Collins, The Sociology of Philosophies, 74. 
bent towards a clear political purpose. These gatherings may have been invitation-only, but an emphasis on their private aspect distorts our understanding of the very public nature of their intent.

\section{A moral authority}

In April 1987, composer John Adams wrote to Betty Freeman one of many letters thanking her for her long-lasting dedication to his career. He recounts the troubling cultural situation that belittled contemporary music, decrying American society as 'chronically indifferent' to the promotion and support of new art. He ends with this declaration: 'You represent something that is absolutely essential to a culture: moral authority. People do listen when you speak. This is something that money cannot buy, and you have it. I feel very lucky to have been a part of your circle of influence.' ${ }^{14}$ Adams's declaration echoes a common sentiment directed towards Freeman, and with good reason. In an era dominated by corporate patronage and competition-based awards from foundations, Freeman offered contemporary composers - mostly those without support from the other major patron, the university - not only money to cover recordings or performances, but also entrance into a community of other composers with her at the nexus. Over the course of her patronage, Freeman at times paid their rent, sometimes housed them, and frequently promoted them around the world. In return, Freeman could boast accolades and dedications for many signature compositions of the last sixty years, including Adams's Nixon in China, Steve Reich's Different Trains, and John Cage's Freeman Etudes. Hers was a life of maternal devotion (she once referred to Adams as her 'golden boy') with adoration returned. Indeed, as Adams's honorific for Freeman implies, her life carried the priestly purpose and often quiet distinction of a moral authority.

Born Betty Wishnick in Chicago in 1921, Freeman spent her formative years in Brooklyn. She inherited her wealth from her father, Robert Wishnick, who emigrated to the United States as a small child and, despite losing most of his right arm in an accident, worked his way through college - and later law school - to become a chemical engineer and founder of manufacturing company Witco. He instilled in her a love for philanthropy, which was echoed by the motto of her alma mater, Wellesley College (Non Ministrari see Ministrare - 'Not to be ministered unto, but to minister'). Wellesley's benefactors, Henry and Pauline Durant, selected the school's motto in the hope that the college would 'inspire the young women at Wellesley to ... become women who would claim a place in the world where in service to others they might attain a sense of fulfillment and power. ${ }^{15}$ In 1942, Freeman graduated from Wellesley, majoring in music and English literature. She pursued further training in piano at Julliard and the New England University ('Wherever I lived I studied music and practiced

14 John Adams to Betty Freeman, 20 April 1987, emphasis added, Betty Freeman Papers, University of California, San Diego Mandeville Special Collections.

15 Arlene Cohen, Wellesley College (Chicago: Arcadia, 2006), 115. In 1989, the college created a mission statement that 'complements and amplifies' the long-standing motto: 'Wellesley College provides an excellent liberal arts education for women who will make a difference in the world' (p. 115). 
piano'), for a time considering a career in performance. ${ }^{16}$ Instead, Freeman married, had four children, and, in 1950, moved to Los Angeles. She later divorced her first husband and married Italian sculptor and painter Franco Assetto.

Working diligently as an art patron and collector, Freeman befriended several major artists. She penned two unpublished books on Clyfford Still and Sam Francis and was the model, and her Beverly Hills home the background, for David Hockney's magisterial Beverly Hills Housewife (1966). It was not until 1961 that Freeman began supporting composers, albeit auspiciously at first. Her first contribution was in the amount of one hundred dollars to help the young composer La Monte Young post bail on a drug possession charge in Connecticut. Young had heard of Freeman's art patronage and wrote her a lengthy letter asking for whatever financial help she could offer in exchange for some of his records. Though she had never met Young she sent the money anyway. ${ }^{17}$

Following her first rather modest contribution, Freeman supported over sixty prominent composers, ensembles, and organizations. Indeed, the list of composers she supported and likewise befriended reads like a veritable Who's Who list of contemporary music: John Cage, Philip Glass, Steve Reich, Harry Partch, John Adams, Harrison Birtwistle, Frederic Rzewski, Morton Feldman, and Kaija Saariaho are only a few (see Appendix for a full list of participants). In return, several pieces have been dedicated to her and a gamelan, built by Lou Harrison, bears the dedicatory title 'Si Betty'. Even with these outward appreciations of her support, however, in the end the extent of Freeman's contributions is difficult to measure. Without her support, many composers and their subsequent works may never have come to fruition. Conversely, it was her work on their behalf that came to define and constitute her life and the meaning she derived from it. As composer and performer Emil Richards later reported, 'When Betty came aboard I was blessed. And we blessed her for being there for all of us.' ${ }^{\text {'18 }}$

\section{Birth of the Music Room}

I remember clearly the epiphany (that's the exact word) that happened to me late one afternoon in 1981 standing in my large sparsely-furnished-but-with-a-Steinway living. It began (the epiphany that is) wishing that someone in Los Angeles would have home performances of contemporary music similar to the mythic Evenings on the Roof of Peter Yates. Simultaneously the realization occurred that that someone was me. I had the space and piano, I had the financial means, I already knew many

16 'Betty Freeman's Address to the California Arts Council, California Institute of Technology, Pasadena, January 27, 1983 (revised April 2003)', The Betty Freeman Collection, Los Angeles Philharmonic Archive.

17 During a radio interview in 2006, Freeman spoke of her initial support of Young: 'So I sent a hundred dollars and I didn't get anything in return. When he got out, he sent me a collection of his records which I listened to and was fascinated. He's somebody who can play one note for four hours, but it's what he does with this one note, with the overtones and the undertones and how he combines it. I became a fan and I'm still a fan all these years'. (Betty Freeman, interview by Vicki Curry, Life and Times, Segment 3: A Patron of Composers, July 14, 2006.)

18 Emil Richards telephone interview by author, October 5, 2008. 
of the important composers - most of all, I had a passion for contemporary music. Even more I had an Italian artist husband who loved to cook ... and would have a good excuse to stay out of the living room. Immediately I telephoned Alan Rich, Los Angeles's brilliant music critic. He enthusiastically agreed to direct the program and suggested we start immediately. ${ }^{19}$

So begins Freeman's unpublished manuscript on her musicales. It is telling that Freeman immediately draws the connection between musicales in her home and those previously hosted in Los Angeles. Both Freeman's and Yates's version of salon culture were designed to alter their surrounding cultural environment in a manner reminiscent of 'niche construction'. Originally a term conceived by evolutionary biologists, anthropologists have recently appropriated niche construction to refer to 'the capacity of organisms to modify natural selection in their environment and thereby act as codirectors of their own evolution as well as that of others. ${ }^{20}$ Evenings on the Roof carried a legendary status for Freeman, perhaps less than for the type of music fostered there - though there are significant musical crossovers than for the ideology behind Yates's enterprise. That is, promoting contemporary music as a relief for modern crises in musical discourse. While Yates believed in a supernatural power manifest when pleasure and musical technique were in union, Freeman believed in the power of a singular community whose music positioned it on the fringe of acceptability. In both cases, it was the benefactor, perhaps more than anyone else, who was in most need of this kind of community.

The Evenings on the Roof series began in 1939, literally on the roof of Peter Yates's and his wife, concert pianist Francis Mullen's, small bungalow. Modernist architect Rudolf Schindler was contracted to build a music studio, which was erected as a second floor, and thus held commanding views of Los Angeles and the Pacific Ocean. The expansion took place during an ongoing financial struggle and personal crisis as Yates sought spiritual solidarity in contemporary music. After returning from a 'long trek in a Theosophists' cooperative community', a vision for what would become his music series opened up before him. He envisioned a space open:

once a week or month to all comers, free or at local movie prices, to give an informal recital without bows, entrances, or exits, performing not only unusual music but also such things as the Bartok children's pieces and often repeating a big work in an evening or in successive evenings ... until both audience and performer have digested it ... Outside artists should be invited to perform works not ordinarily allowed them in recital, their fee being the evening's take. In every case it should be impressed on the mind of each player that the primary reason for his performance

19 Preface to unpublished manuscript entitled 'Salotto: Composers and Their Music', The Betty Freeman Collection, Los Angeles Philharmonic Archives.

20 Michael J. O’Brian and Kevin N. Laland, 'Genes, Culture, and Agriculture: An Example of Human Niche Construction', Current Anthropology 53/4 (August 2012), 434. 
is his own pleasure in it, that if the audience be small or absent that is no reason for personal disappointment or loss of pleasure ... Such is the community idea. ${ }^{21}$

Yates's utopian vision, ordered by contemporary music, stands in contrast to his total rejection of authority, as Dorothy Lamb Crawford describes: 'Yates was completely opposed to authoritarianism and the bureaucratic controls he saw in his office work and in prewar Europe. He despised the excesses of capitalism and, like many others in the 1930s, was interested in theoretical communism.' 'More and more I am a revolutionary', Yates wrote, 'not for causes, but against the deceitful slack-fisted lazy-souled or soulless viciousness of human ways $\ldots$ and I too day after day am slugged by this fear, fear of losing livelihood. ${ }^{\text {'22 }}$

For Yates, the role of art was 'to find again the integrating power in a disintegrating universe of superficiality. ${ }^{23}$ Freeman's concept of a musicale was less theoretical but equally self-conscious. I have written elsewhere about the distinctive maternal relationship Freeman maintained with several of the composers she supported. ${ }^{24}$ Similarly, she often claimed a matronly attachment to the pieces she commissioned, writing for example of Christopher Rouse's Cello Concerto, 'I'm proud that it's my commission-I feel to be a proud mama.'25 From these accounts, it seems Freeman placed a premium on the relational bonds developed between herself and those she supported. If her purpose in supporting new music was fostering the music itself, it certainly included on equal footing fostering also those who wrote the music. In Freeman's musicales, then, a community organized in her home could provide her need for maternal order while coalescing other, powerful people in the larger musical community to set in motion the widening influence of contemporary music.

Yates's ideology and Freeman's matronly instinct initiated a salon tradition in Los Angeles to, in the spirit of Habermas, use the gathering power to claim the public sphere against cultural authorities within the larger public sphere. In this way, Freeman's claim to lineage with Yates unites her musicales as instrumental in their affective purpose to alter their environment. The social gatherings Freeman hosted in some ways constituted a moralist endeavour. The Music Room became the grounds for which ideas concerning the edifying power of contemporary music could displace prevailing musical sensibilities that dismissed or made no room for them. In so doing, the power of that small public, as 'carrier of public opinion', earnestly sought for a better community.

\section{Thirty-three by twenty-eight feet}

Alan Rich never intended on staying in Los Angeles. He moved there in 1979 'ostensibly for a year' to serve as music critic for a new magazine. He never left and, as he once wrote, 'Betty

21 Quoted in Dorothy Lamb Crawford, Evenings On and Off the Roof: Pioneering Concerts in Los Angeles, 1939-1971 (Berkeley: University of California Press, 1995), 21.

22 Crawford, Evenings On and Off the Roof, 29.

23 Crawford, Evenings On and Off the Roof, 30.

24 See Jake Johnson, 'Performing the Patron: Betty Freeman and the Avant-Garde', TEMPO 68/269 (July 2014).

25 Freeman to Adams, 1 February 1994, Betty Freeman Papers, University of California, San Diego Mandeville Special Collections. 
Freeman is one of the reasons.' Rich was originally from Boston, having studied music first at Harvard and then entered graduate study in musicology at the University of California, Berkeley. While in Berkeley, Rich served as music director for KPFA, a radio station legendary both for using the public airwaves to oppose American military action abroad and for the fervent support and subsequent broadcasting of contemporary art music. He worked as a music critic for a host of publications, including the New York Times, Newsweek, Boston Herald, and LA Weekly - the latter a post he maintained for sixteen years, parting ways just two years before his death in 2010 .

Rich recalled his first meeting with Freeman in her home, where they discussed her idea of beginning a musicale series:

At lunch ... Betty told me that one of her fears was that there might be composers out there in need of help, whom she hadn't heard about. I told her that I probably knew a few of those composers, and that I'd be glad to bring them around to meet Betty and play her some of their music. 'Oh, fine', she said. 'And I'll invite a few friends over, and Franco will make pasta, and it will be like a salon.'26

Rich thus began what would become an engrossing and exhausting fourteen years as coorganizer and master of ceremonies. The musicales brought Freeman and Rich together and, ironically, the subject of the musicales ended their relationship under bitter terms. Much like the competing interests of Mrs Harley Manners and Philip Studley in The Soul of a Tenor, this patron and music critic grew to find one another's presence intolerable. When reviewer comments for their book manuscript on the musicales returned with critical suggestions, Freeman took offence and abandoned the project altogether. Rich was furious. Freeman had entered the project more or less as a producer, guaranteeing the costs not only of the production but also of its distribution, making her book available for free to every music library in the country. Following the fallout, both Freeman and Rich separately warned me of the other. Rich felt that discussing contemporary music 'was for the most part beyond her comprehension', adding that 'she loves being involved in the arts, quite sincerely, and loves the arts themselves, quite limitedly. ${ }^{27}$ For her part, Freeman suggested I meet with Rich at his home rather than a combined lunch meeting at hers, writing that 'he has become strange and difficult. Something I do not understand. ${ }^{28}$ This was in 2009. In 1981, though, things were much brighter between the two and, on 25 October, the first musicale, featuring composers Earle Brown and David Hush, took place at 703 Hillcrest Road in Beverly Hills.

Although its beginnings were meagre, over the years Freeman's 'few friends' grew to number as many as one hundred, sometimes uncomfortably crammed into her home. Hers was not the palatial Beverly Hills mansion of popular imagination. On the contrary, the room designated for the musicales was designed for more curatorial purposes. One observer

26 'Salotto', Los Angeles Philharmonic Archive.

27 Email from Rich to author, 21 October 2008.

28 Letter from Freeman to author, 25 June 2008. 
remembered that 'performances [took] place in the thirty-three-by-twenty-eight-foot living room, its walls painted black the better to display a huge, largely white "edge painting" by Sam Francis, a light construction by Douglas Wheeler, and two works by Roy Lichtenstein. ${ }^{29}$ A quick glance at Freeman's photographs taken at these events makes clear the level of coziness these gatherings encouraged. Aside from the first two musicales, all events were professionally recorded, which introduced more intrusion into the space. The large white canvas painting often handily functioned as a place to project images during musicales, though it was also the wall opposite the grand piano. As composers spoke or demonstrated passages at the piano, they frequently referenced images projected on the opposite wall. The audible scuffing of chairs and craning of necks litter the musicale recordings. 'There were times when the crowds pushed fairly hard against the walls', Rich remembered. 'I saw [Freeman] go pale only once ... when Lou Harrison showed up with the twenty members of his gamelan, exotic Indonesian percussion instruments and all. We deployed them up and down the staircase leading up to the bedrooms, and their sounds filled the house most gloriously. ${ }^{30}$ While not ideal conditions, guests looked beyond the limitations of the physical space. Wallace Smith, then general manager of southern California's classical music station KUSC, opined 'The musicales keep me connected with what's going on in contemporary music. They're the one event I will move other engagements off the calendar for.' ${ }^{31}$

As the crowds gathered, Rich called each musicale to order with the ringing of wind chimes based on Harry Partch's tuning. While LaMonte Young's bail-out money may distinguish him as the first composer to receive Freeman's patronage, Harry Partch surely held a special place in Freeman's heart, as she did in his. It was meeting and working with Partch after an event at the Pasadena Art Museum in 1965 that propelled Freeman into the realm of patronage. Freeman paid his rent, helped him buy his house, paid for the almost constant moving of his handcrafted but bulky instruments, and secured performances and recordings of his work. Perhaps most prominently, though, is Freeman's producing the Partch film The Dreamer that Remains. It was at a screening of this film in her home in 1981 that Rich first met Freeman, over lunch that day that the actuality of the Music Room was put in motion, so it seems fitting that the call to order for these musicales would be from Partch's musical imagination.

The typical evening's (or sometimes afternoon's) events proceeded as follows: Freeman or Rich (and later Judith Rosen) would focus the group on pertinent news and information. These were monthly musicales, so at times a lot of information had to be shared. Upcoming concerts or lectures were announced, guests new to the musicales were introduced and welcomed, that evening's programme was explained, composers appearing at the subsequent musicale were announced, and, of what seems to have been a particular delight and draw

\footnotetext{
29 Barbara Jepson, 'A Cultivated Ear: Betty Freeman's Living Room is the West Coast's Center for New Music', Connoisseur, February 1987.

30 'Salotto', Los Angeles Philharmonic Archive.

31 Jepson, 'A Cultivated Ear'.
} 
for the musicales, the pasta dish for the evening was unveiled. While a noted sculptor and inventor, for these occasions Freeman's second husband Franco Assetto attuned his inventive abilities to pasta sauces. Assetto 'disliked contemporary music, preferring Verdi and Rossini', so he busied himself with dinner. ${ }^{32}$ If the occasional giggle or gasp from audience members interrupted the flow of a composer's thoughts, it was only in response to the boisterous Italian swearing emanating from the kitchen. Yet, from all accounts, the pasta was superb. During one musicale introduction, Freeman announced that she was sponsoring a particular new music festival and urged others to contribute as well, adding that if all those in attendance did not, they would be dropped from the Music Room mailing list. When later asked if that ultimatum alienated anyone of prominence, she coolly replied 'No, they were the people who came to eat the pasta.' 33

Following introductions, Rich introduced the invited composer, often adding some report of malfeasance a less-understanding music critic had bellowed against a recent performance of that composer. For Rich, Los Angeles was entering into a vital transformative stage in global perception. Like Peter Yates and, like many others in attendance, Rich felt that new music was a balm to heal the wound of Los Angeles's sneered past as a cultural wasteland. Opening up each musicale by focusing on critical reception, often by critics from New York - the nemesis of many Angelenos fighting for their city's cultural relevancy - Rich defined the evening's gathering from a negative space. This may have served many purposes, not the least of which being a curt apology to the visiting composer on behalf of understanding fans. Even more, though, Rich's stance introduced an insider/outsider dichotomy that not only privileged the opinion of those gathered at the musicales but also allowed him and all those gathered to perceive of themselves as a group whose private assembly had a political and cultural purpose beyond or in defiance with that of the larger public. If there was a war to be waged with the perceived outside cultural world, then Rich was arming his group of Davids with the largest stone in their sling.

The nature of each composer's discussion varied widely. Most of the time, two composers spoke for about an hour and a half each. These discussions almost always included musical performances, in part if not whole. The only exception, aside from the few times nonmusicians were featured at musicales - artist David Hockney; Marta Feuchtwanger, émigré and widow of writer Lion Feuchtwanger; director Robert Wilson, and librettist Jack Larson - was when Pierre Boulez agreed to come under the condition that he only discuss his music. Otherwise, composers played tape performances or paid musicians were invited to perform. Some composers preferred to let the music speak for itself; others only used brief musical examples to punctuate complicated discussions. Often one invited composer enjoyed a national or international career while the other was a local or burgeoning composer. Frequently the audience was peppered with young composers and faculty composers from the area.

32 'Salotto', Los Angeles Philharmonic Archive.

33 Jepson, 'A Cultivated Ear'. 
The most constant figures at the musicales, however, were prominent and serious members of the larger Los Angeles musical community. Ernest Fleischmann, then the executive director of the Los Angeles Philharmonic and a regular attendee, described the audience as 'a small group of influential decision makers in Los Angeles - people responsible for producing new-music events or encouraging their production. ${ }^{34}$ Indeed, the list of regulars is impressive. Composer and musicologist Nicolas Slonimksy 'had an almost perfect attendance record until his death at 102'. Lawrence Morton, who inherited Yates's Evenings on the Roof series and transformed them into Monday Evening Concerts, also regularly attended until his passing. Marta Feuchtwanger, whose Palisades home fostered hosts of intellectuals and artists fleeing Nazi Germany, attended until her death in 1987, sitting 'enthroned like some legendary dowager in a robe of black and gold, not merely a presence but a Presence. $^{35}$

A period of questions immediately followed each composer's presentation. Of course, the nature and dynamics of these discussions varied widely and, if the wafting smells of Franco's pasta proved too urgent a temptation, Rich quickly ended them. As dinner was served, guests were directed to sign the guest book, beautifully leather bound and inscribed 'Il Salotto Musicale' (Salotto being Franco's word for the musicales - 'big salon'). The book now resides in the Los Angeles Philharmonic Archive. Signatures, drawings, musical notation, and poetry fill the pages as a physical reminder of the transference of new ideas the musicales provided. Not only did guests mingle and build networks with composers present but they also flipped through the pages to find a connection to those gone before. By refocusing attention on the musical past and thus back to the nature of their gathering, the book became what Collins would call a 'sacred object'. The ability to focus the group inherently lies in the text itself: 'Writing enables one to transcend the immediate present; it is a gateway to abstraction and generality.' ${ }^{36}$ In 'Il Salotto Musicale', the conditional requirements for providing an interaction ritual, as per Collins's conception, are thus met as this 'sacred object' retains the focus on the function of the musicales themselves.

\section{Changing hands}

After Assetto's death in 1991, Freeman decided to pass along the musicales to someone else. Judith Rosen, along with husband Ron, regularly attended Freeman's musicales. Rich approached Rosen in 1991 to ask if she would be willing to continue the musicales in her home

34 Jepson, 'A Cultivated Ear'.

35 'Salotto', Los Angeles Philharmonic Archive. Marta and Lion Feuchtwanger bought Villa Aurora in Pacific Palisades in 1943. The home became an important center of Jewish emigre intellectual and artistic activity throughout the war years and well beyond. The Villa Aurora now serves as an artists' residency which, according to the Villa's website, houses 'writers and journalists whose freedom of expression is hampered in their own country'. See www.villa-aurora.org/en/artists-residence.html.

36 Collins, The Sociology of Philosophies, 27. 
in the San Fernando Valley. She obliged, noting only 'a brief hesitation led to an enthusiastic embracing of the offer'. Rosen had a keen sense of the networking potential the musicales offered, writing that the socializing following each musicale served as the "'golf course" of the new music scene' with 'several commissions and future contacts sealed'. She took over where Freeman left off, sharing the organizational responsibilities with Rich, opening her home for the events themselves, and even providing dinner in honor of Franco, but never in imitation-pasta was never served! 37

Freeman still remained a presence at the musicales, however, frequently walking around the room taking pictures, as she had during the ten years' worth of musicales before. According to Danlee Mitchell, he handed Freeman a camera during the filming of The Dreamer that Remains and that is when her passion for photography ignited. ${ }^{38}$ Throughout her life, she felt drawn to photograph the many musical figures she supported. She published several books of her photography, titled Music People, and was working on a photo-biography on Harry Partch when she died. The Los Angeles Philharmonic Archive houses over seven thousand unpublished photographs Freeman took over the years, not including the hundreds taken at the musicales. Freeman felt it was part of her patronage to photograph those she supported and indeed we have Freeman to thank for the many excellent images of the most influential figures from the American and European avant-garde.

Not only did she take pictures, but Freeman was also the inspiration for several portraits, both visual and musical. As discussed earlier, Freeman and her home were models for David Hockney's Beverly Hills Housewife. Hockney had been painting swimming pools in southern California and, having been introduced to Freeman through the actor Jack Larson, Hockney learned of Freeman's devotion to the avant-garde and decided then that he would use Freeman and her home as models for his painting. ${ }^{39}$ Hockney created a video composite of Freeman in 1991 as well, and also pencilled a more realist rendering of Freeman later in life, one that resembles in nature a portrait by her friend, composer Virgil Thomson. Thomson initiated what he called his 'musical portraits' while his subject sat before him, 'making musical portraits as a painter works, in the model's presence. ${ }^{40}$ Of the 140 musical portraits he composed, one captured Freeman and another her husband Assetto while all three were vacationing in Greece. As Freeman remembered, 'Both the musical portraits of me and my husband were made on the Greek island of Corfu in 1981 when Virgil was our guest there for five weeks in the summer.' ${ }^{41}$ Freeman's musical portrait, entitled 'Dead Pan: Mrs. Betty Freeman', features a somewhat canonic, slow moving figure that, as its title suggests, gives little impression or excitement; rather, Freeman's more stoic musical portrait contrasts sharply with the scarcely harnessed energy of Assetto's, entitled 'Franco Assetto: Drawing

37 'Salotto', Los Angeles Philharmonic Archive.

38 See Jake Johnson, 'Two Studies on Harry Partch: Conversations with Danlee Mitchell and Betty Freeman', Echo: A Music-Centered Journal (Fall 2014).

39 In May 2009, a few months after her death, Beverly Hills Housewife was sold in auction for \$7.9 million.

40 Anthony Tommasini, Virgil Thomson's Musical Portraits (New York: Pendragon Press, 1986), x.

41 Quoted in Tommasini, Virgil Thomson's Musical Portraits, 180. 
Virgil Thomson' - the title indicative of Thomson's insistence that the portrait 'took place while the artist was sketching the composer. ${ }^{42}$ Of the musical depiction that Thomson made of her husband, Freeman lauded Thomson's realistic rendition: '[Assetto] is as energetic and explosive as V's portrait of him and has great gusto for life. ${ }^{43}$ Thomson would later counter any claims for realism in his portraits, noting that their 'value to characterization ... can only be metaphorical. ${ }^{44}$ Albeit metaphorical, Thomson's musical personification of Freeman adds to the unusual and rich relationship Freeman shared with portraiture. Even though Freeman had relinquished control over the Music Room, her insistence on photographically documenting the musicales continued her presence as more than a mere guest in Rosen's home.

Rosen lent her particular passion for women's issues to her organization of the musicales. Although Freeman carried no bias against supporting women composers - she was a devoted champion of Kaija Saariaho late in life, for example - Rosen's interest in new music was tied to her interest in women's involvement with music:

I became involved with music being written today because of an interest in music by women, which started some twenty years ago. I had to familiarize myself with contemporary music or I didn't know how to differentiate anything about the tapes that I was receiving from women all over the country who hoped I would put their music on the radio shows I was doing at the time. I knew of Steve Reich's music because he was on the flip side of a record I had of Pauline Oliveros's music. I found out a lot about contemporary music because I was collecting music by women. ${ }^{45}$

Nonetheless, matters did not change drastically: for the final three years of musicales, out of the total twenty-five composers only five were women. Rosen did not want to invite a composer solely on gender, but she brought to the Music Room a new level of attention to women composers. 'I can't just [invite] a woman because she's a woman', she once announced at a musicale. 'I really believe that very strongly after twenty years of all the research and writing and lecturing that I've done. ${ }^{46}$

Believing the musicales to be 'a laboratory for the development' of new music, Rosen saw the Music Room to its end. After thirteen years, seventy-two events hosted at two locations, and 132 invited composers, the final musicale took place in her home on 17 April 1994, featuring only one composer, Esa-Pekka Salonen - then conductor of the Los Angeles Philharmonic. Freeman was there. Salonen represented a new era in the Los Angeles musical culture, one that heralded commissions and world premieres on an unprecedented level. It seems fitting,

42 Tommasini, Virgil Thomson's Musical Portraits, 182.

43 Tommasini, Virgil Thomson's Musical Portraits, 183.

44 Tommasini, Virgil Thomson's Musical Portraits, ix.

45 Tape recording of musicale featuring Anthony Braxton and Libby Larsen, Judith Rosen Collection, Stanford University Archive of Recorded Sound.

46 Tape recording of musicale. 
then, for the Music Room to come to a close by featuring the man who had helped carry the hope of contemporary music to Los Angeles and, as a city then on the cultural radar, by extension to the rest of the world.

\section{Conclusion}

Sociologist Paul McLean writes:

Our careers are made - and we are made - through our interactions with others, as well as through the performance of those tasks to which we have access by virtue of our connections to others. We become more fully the persons we are through interaction, our personhood being constructed out of a number of different identities we adopt, singly or in combination, in different interactional settings. We may achieve autonomy, and achieve a private conception of self independent of attributions of identity put upon us by others, through the accumulation of multiple network ties and participation in social interaction coursing across multiple networks and diverse cultural domains. ${ }^{47}$

As McLean notes, networked interactions provide a vehicle for self-realization and also serve to position that self in relation to a kind of community of work. This echoes Bourdieu's contention that 'The existence of a network of connections is not a natural given ... It is the product of an endless effort at institution. ${ }^{48}$ The Music Room, in facilitating such an 'endless effort at institution', granted the contemporary music scene a space - an 'interaction ritual' - for networking to occur. Not only that but it also allowed Freeman a space where her own identity as matron of modern music could be realized.

'Without [Freeman], American music ... would have lacked not only a generous patron but a formidable champion and a closely engaged comrade as well', wrote the New York Times in 2001. ${ }^{49}$ For all her singularity, Freeman's contribution continued a much larger trend in salon culture. She began, and Rosen finished, what Peter Yates dreamed. All three supported new music in Los Angeles with very simple means: a home, generously offered, with music to share with friends. As a result, the impact of this form of patronage reverberates backwards and forwards through time. The salon culture that the Music Room procured enabled guests to inherit the centuries-old tradition of idea exchange within salon culture. This particular manifestation of idea exchange came to a close over twenty years ago. If there is anything true to the trajectory of history, somewhere a group of thinkers is meeting, building networks, exchanging ideas, and exploring new intellectual or artistic territories. The space may change, but the ordained purpose of the salon continues its ancient conversation of ideas and their exchange, of identity and its sustaining, of assembly and mingled voices.

47 Paul D. McLean, The Art of the Network: Strategic Interaction and Patronage in Renaissance Florence (Durham: Duke University Press, 2007), 1-2.

48 Quoted in McLean, The Art of the Network, 11.

49 Paul Griffiths, 'Paying Homage to a Musical Muse, Betty Freeman', New York Times, 24 May 2001. 


\section{Appendix: Music Room programs 1981-94 At Betty Freeman's home Beverly Hills, CA}

25 October 1981

6 December 1981

3 January 1982

31 January 1982

8 March 1982

4 April 1982

7 November 1982

5 December 1982

16 January 1983

13 February 1983

6 March 1983

13 November 1983

11 December 1983

8 January 1984

29 January 1984

4 March 1984

11 November 1984

9 December 1984

6 January 1985

10 February 1985

3 March 1985

3 November 1985

1 December 1985

12 January 1986

9 February 1986

2 March 1986

27 April 1986

9 November 1986

7 December 1986

11 January 1987

8 February 1987

3 March 1987

5 April 1987

15 November 1987

6 December 1987

10 January 1988

7 February 1988
David Hush, Earle Brown

Pia Gilbert, Charles Amirkhanian, Virgil Thomson, Earle Brown

Robert Erickson, David Raksin

Philip Glass

John Cage, Nicolas Slonimsky

Joan LaBarbara, Morton Subotnick, David Hockney

William Kraft, John Adams

Janis Mattox, Loren Rush, Robert Wilson

Steve Reich

Rhonda Kess, Marta Feuchtwanger

Dorrance Salvey, Lou Harrison

Mel Powell, Carl Stone

Henri Lazarof, Rand Steiger

Paul Dresher, Halsey Stevens

Conlon Nancarrow, Nicolas Slonimsky, Eva Soltes

Bernard Rands, Daniel Lentz

Luciano Berio, Jack Larson

Roger Reynolds, Harold Budd

Terry Riley, Barry Schrader

Morton Subotnick, Leonard Rosenman

Andrew Imbrie, Louis Andriessen

John Adams, Conlon Nancarrow

Ingram Marshall, Henry Brant

Morton Feldman, George Heussenstamm

Peter Garland, Charles Shere

Milton Babbitt, Charles Dodge

Frederic Rzewski, Ted Peterson

Pauline Oliveros, Steven Mosko

Steve Reich

Gordon Getty, Fred Myrow

John Harbison, Richard Felciano

Pierre Boulez

James Tenney, Brian Ferneyhough

Ned Rorem, David Rosenboom

Gerhard Samuel, Paul Lansky

John Adams, John King

Ed Applebaum, Rand Steiger 
408 Johnson The Music Room: Betty Freeman's Musical Soirées

\begin{tabular}{ll} 
6 March 1988 & Mauricio Kagel, Kraig Grady \\
24 April 1988 & David Behrman, Mark McGurty \\
6 November1988 & Charles Amirkhanian, Malcolm Goldstein \\
4 December 1988 & Frederick Lesemann, Daniel Lentz \\
8 January 1989 & Tod Machover, Paul Dresher \\
5 February 1989 & David Cope, Will Ogden \\
5 March 1989 & Gregg Wager, Poul Ruders \\
9 April 1989 & Laura Karpman, Kaija Saariaho \\
22 October 1989 & Philip Glass \\
12 November 1989 & Oliver Knussen, Janice Giteck \\
3 December 1989 & Aaron Jay Kernis, Esa-Pekka Salonen \\
23 January 1990 & Steven Stucky, Michael McNabb \\
11 February 1990 & John Bergamo, John Naples \\
4 March 1990 & Jacob Druckman, Sheila Silver \\
1 April 1990 & Charles Wuorinen, Donald Crockett \\
9 September 1990 & John Adams and Peter Sellars \\
14 October 1990 & Anthony Davis, Frank Royon Le Mée \\
16 December 1990 & Mel Powell \\
6 January 1991 & Witold Lutoslawski, Joji Yuasa \\
10 February 1991 & John Harbison, Chinary Ung \\
3 March 1991 & George Perle, David Ocker \\
31 March 1991 & Brian Kehlenbach, Gordon Mumma \\
& \\
\hline
\end{tabular}

\section{At Judith Rosen's home Sherman Oaks, CA}

10 October 1991 Stephen Hartke, Carlos Rodriguez

1 December 1991 Silvano Bussotti, William Kraft

2 February 1992 Christopher Rouse, Olly Wilson

23 February 1992 Aulis Sallinen

17 May $1992 \quad$ Pierre Boulez and John Chowning

4 October 1992 Anthony Braxton, Libby Larsen

25 October 1992 Mel Powell, Joan Huang

6 December 1992 Alexander Goehr, Joanna Bruzdowicz

28 February 1993 Gyorgi Ligeti

21 March 1993 Voyager Co., Morton Subotnick, Alan Rich

25 April 1993 Roger Reynolds, Leonard Rosenman

16 May 1993 Shulamith Ran (in absentia), Steven Stucky

12 January 1994 Elliott Carter

27 February 1994 Bernard Rands, Augusta Read Thomas

17 April $1994 \quad$ Esa-Pekka Salonen 


\section{Bibliography}

Barr, Cyrrila. Elizabeth Sprague Coolidge: American Patron of Music. New York: Schirmer Books, 1998.

Cohen, Arlene. Wellesley College. Chicago: Arcadia, 2006.

Collins, Randall. The Sociology of Philosophies: A Global Theory of Intellectual Change. Cambridge, MA: Harvard University Press, 1998.

Crawford, Dorothy Lamb. Evenings On and Off the Roof: Pioneering Concerts in Los Angeles, 1939-1971. Berkeley: University of California Press, 1995.

Freeman, Betty. Interview by Vicki Curry, Life and Times, Segment 3: A Patron of Composers, 14 July 2006.

Goodman, Dena. The Republic of Letters: A Cultural History of the French Enlightenment. Ithaca: Cornell University Press, 1994.

Griffiths, Paul. 'Paying Homage to a Musical Muse, Betty Freeman'. New York Times, 24 May 2001.

Habermas, Jurgen. The Structural Transformation of the Public Sphere: An Inquiry into a Category of Bourgeois Society, trans. Thomas Burger. Cambridge, MA: MIT Press, 1989.

Henderson, W. J. The Soul of a Tenor: A Romance. New York: Henry Holt, 1912.

Jepson, Barbara. 'A Cultivated Ear: Betty Freeman's Living Room is the West Coast's Center for New Music'. Connoisseur, February 1987.

Johnson, Jake. 'Performing the Patron: Betty Freeman and the Avant-Garde'. TEMPO 68/269 (July 2014), 42-9.

—. 'Two Studies on Harry Partch: Conversations with Danlee Mitchell and Betty Freeman'. Echo: A Music-Centered Journal 12/1 (Fall 2014). www.echo.ucla.edu/two-studies-harry-partch-conversationsdanlee-mitchell-betty-freeman-jake-johnson/ (accessed 26 September 2017).

Locke, Ralph P. and Cyrilla Barr, eds. Cultivating Music in America: Women Patrons and Activists since 1860. Berkeley and Los Angeles: University of California Press, 1996.

McLean, Paul D. The Art of the Network: Strategic Interaction and Patronage in Renaissance Florence. Durham, NC: Duke University Press, 2007.

O’Brian, Michael J. and Kevin N. Laland, 'Genes, Culture, and Agriculture: An Example of Human Niche Construction'. Current Anthropology 53/4 (August 2012), 434-70.

Richards, Emil. Telephone interview by author, 5 October 2008.

Rousseau, Jean-Jacques. Politics and the Arts: Letter to M. d'Alembert on the Theatre, ed. and trans. Allan Bloom. Ithaca: Cornell University Press, 1968.

Tommasini, Anthony. Virgil Thomson's Musical Portraits. New York: Pendragon Press, 1986.

Warner, Michael. Publics and Counterpublics. New York: Zone Books, 2002. 